\title{
Improving Students' Cognitive and Affective Domains Students through Fostering Teacher Development
}

\author{
Kurniati Kurniati ${ }^{1^{*}}$,Nurdin Nurdin ${ }^{2}$, and Nurasmawati Nurasmawati ${ }^{3}$ \\ ${ }^{1}$ Islamic Education Department, Postgraduate, Institut Agama Islam Negeri Palu \\ 2 Islamic Education Department, Postgraduate, Institut Agama Islam Negeri Palu \\ ${ }^{3}$ Islamic Education Department, Postgraduate, Institut Agama Islam Negeri Palu
}

\begin{abstract}
The aim of this paper is to discusses the practice of cousin marriage in the community of Kalola Village, Pasangkayu Regency, West Sulawesi. This study uses qualitative methods and data was gathered through observation, in-depth interviews, and written material. Data analysis was analyzed using grounded theory approach. The results showed that the foster teacher pattern applied in MAN Insan Cendekia Palu City was a form of activity and guidance that was relative and consistent, and a series of active efforts that made a large contribution to students, in improving intellectual / academic aspects as well as good attitudes. . So that the foster teacher pattern is used as a series of activities as a vehicle to educate, nurture and socialize children in developing their abilities, in order to achieve family, community and school expectations. Some educators who serve as foster teachers apply authoritarian parenting with the aim that students are clear and do not repeat mistakes, and also authoritative parenting which provides more understanding and good guidance without heavy pressure and punishment.
\end{abstract}

ARTICLE

INFORMATION

\section{Keywords:}

Students, cognitive, affective, fostering, teacher development 


\section{Pendahuluan}

One by one, many educational institutions at the junior high and high school levels under the Ministry of National Education have implemented the boarding school system as one of the leading programs. The boarding school system that is applied in the educational process does not rule out that it is strongly influenced by the values of "boarding school" that exist in Indonesia in general and becomes a kind of guideline in an effort to improve the quality of the nation's generation.

With the spirit of integration between religious education and general education, as well as between Islamic sciences ('ulum syar'iyah) and natural sciences (' ulum aqliyah) public schools do not want to be left behind in striving to improve, and to form student's intelligence. Wholeness is meant between the development of the ability of reason and students' intellectuals are balanced with the quality of faith and devotion to Allah.

The learning system of the Islamic Junior High School Boarding School Jabal Hikmah is an educational model that is an alternative solution to meet the demands that all circles covet. By implementing two educational models, namely general and religious education (boarding school) which is determined to make future generations have a balanced competence, between qauniyah and qauliyah, between fikriyah, ruhiyah, and jasadiyah $^{1}$ so as to be able to

${ }^{1}$ Rusli, R. (2014c). Teaching Usul al-Fiqh: A Multicultural Education Model. Al-Tahrir: Jurnal Pemikiran Islam, 14(2), 447-464. produce young generations of Muslims who are knowledgeable, have broad insight and beneficial to the people. Of course, this wish is not just a dream but something that is expected to happen and even to be carried out. However, the process to achieve it is certainly not easy and there are many obstacles that must be faced.

This boarding - patterned education is actually a combination of the public school education system with the boarding school education system where students receive 24-hour education. This education model offers advantages that are measured in terms of the readiness of students to become believers and pious people, and are able to live independently in society. ${ }^{2}$

The purpose of Boarding School education is something (desire or aspiration) to be achieved. Goals include the keys to educational success, as well as the associated factors: educators, educational tools and the educational environment. $^{3}$

MAN Insan Cendikia, especially in Palu City, is a school that also implements a boarding school system, which requires students to attend regular educational activities from morning to evening, and night such as; Al-Quran study activities, extracurricular activities, disciplinary fostering activities and so on. In this case there is coaching from a teacher who has

2Murtadho, Kumpulan Sinopsis Hasilhasil Penelitian Agama dan Keagamaan, (Program Peningkatan Kualitas Pelayanan Publik: Badan Litbang dan Diklat Departemen RI, 2006), 100.

${ }^{3}$ Mujamil Qomar, Pesantren dari Transformasi Metodologi Menuju Demokratisasi Institusi, (Jakarta: Erlangga, 2007), 3.

e-ISSN: $2715-4572$ p-ISSN: 2716-1439 
been selected as a foster teacher. In this coaching, a foster teacher is tasked not only in improving the intellectual aspect but also in shaping the character or attitude and values that arise as a result of the stimulus that has been given in the learning process.

However, are the strengths and advancements possessed by the Insan Cendikia State Madrasah Aliyah in Palu City have carried out coaching especially for foster teachers on cognitive and affective aspects properly? Does this school, which is known for their boarding school system, obtain alumni who have the potential in cognitive and affective aspects in accordance with the expectations of their parents, especially at Madrasah Aliyah Negeri Insan Cendikia in Palu City, which specializes in fostering students, namely providing dormitories or a place to live in the school environment, so that students interact more with teachers at school and caregivers in dormitories.

Boarding-style education as an alternative for several educational institutions that want an increase in the quality of education for their students is always trying to be the best institution and in demand by the public. This education also takes place by using boarding facilities as a residence for students, educators and those directly involved in the educational process referred to as a boarding school, pattern education.

The aims of this education include: (1) to form the personality of students as a whole, namely the application of three educational domains; cognitive, affective and psychomotor; (2) to emphasize the application of the function of educators not only as a teacher but also as an educator, mentor / coach, trainer, as a motivator, innovator and at the same time as an initiator; (3) to facilitate educators in controlling over students, or the other way around; (4) creating a democratic and harmonious family atmosphere; (5) establish discipline and independence of students, especially in learning and practicing worship.

Cognitive, affective and psychomotor aspects are educational targets developed by teachers in the learning process, these three aspects are educational goals that must be achieved after taking the educational process. First, the cognitive aspect, namely the science (intelligence) of students. Second, the affective aspect, namely the attitude of students. Third, the psychomotor aspect, namely the skills (deeds / charity) of students.

This study will observe and find out what patterns are carried out by foster teachers in improving the cognitive and affective domains of their students, both in terms of knowledge and attitudes. Like what form of activity and its purpose in fostering students.

In fact nowadays, what is often developed is cognitive, possibly because it is easy to implement and the evaluation given is not difficult, so that students only acquire knowledge. Because of this, the responsibility or mandate given is not carried out properly. The function of the teacher is not only as a transfer of knowledge, but the function of the teacher is as an educator, motivator, guide towards a better direction, especially in shaping 
the morals (attitudes) of students. Education that is expected by students who are smart, have good morals and apply intelligence by doing or showing good behavior. 4

In line with the description above, the purpose of education is so that behavior changes in the person who is learning. Behavioral changes can occur in three domains, namely: changes in the cognitive domain in the form of stronger concepts of knowledge, affective changes in the form of growing and increasing awareness and awareness of the function and meaning of the knowledge they currently have, and psychomotor changes that show the increasingly developed skills that are now and later it can cause them to be able to defend themself. ${ }^{5}$

Education is an important thing, and it has become a necessity that cannot be postponed anymore, so in order to create a future generation, it is necessary to have educational institutions that can provide comprehensive education, both in terms of intellect, attitudes and skills. This educational model is widely applied to educational institutions where students live in dormitories.

One of the important elements in the boarding education system is the field of care. Parenting activities as part of educational efforts are carried out in

${ }^{4}$ Abdul Kader, Dkk, Dasar-Dasar Pendidikan, (Jakarta: Kencana Media Group, 2012), 79.

5Sukardjo dan Ukim Komarudin, Landasan Pendidikan: Konsep dan Aplikasinya, (Jakarta: Rajawali Pers, 2010), 11. order to grow, develop and strengthen the personality of students.

Several educational institutions apply the methods of coaching and guiding students through parenting activities as a curriculum that is integrated with educational efforts. Where students are required to take part in parenting activities as one of the requirements to go to the next level / class. Some others do not apply it as a curriculum but still serve as guidelines for following education in the dormitories.

Coaching and mentoring of students through fostering is a planned effort to develop creativity and insight to realize the character of students so that intellectual balance, emotional and spiritual intelligence are formed. ${ }^{6}$

\section{Literature review}

\subsection{Forms of Parenting}

Parenting is one of the factors that affect the quality of education. Experts state that no matter how good a curriculum is, the results also greatly depend on how the parenting styles are applied during teaching and learning activities. As previously we all know that in the quality of learning also by the attitude of educators and creative styles in choosing and how to implement learning approaches and models. In this case the form of parenting teachers or educators in question is the ability of a teacher to create something new in learning that can influence creativity in

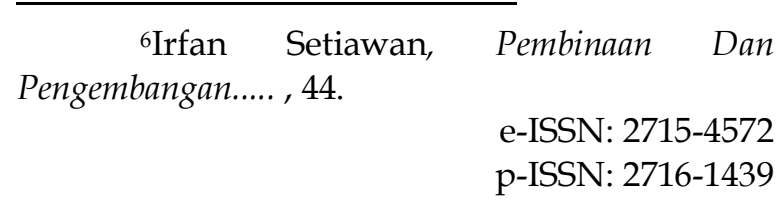


children. The form can be in the form of ideas filled with action.

Parenting is also a system or way of educating and coaching given by one person to another. In this case, the parenting style given by parents or educators to children is to nurture and educate them with understanding. As we also know, things that can affect the parenting style given by both parents and educators are the internal and external social environment. These two things are very influential. Therefore, children's creativity cannot be separated from the care of either parents or an educator.

Several types of parenting styles, several types of parenting, are as follows:

1. Authoritative Type

Parents or educators with authoritative types will fully accept and involve children. In this case, both parents and educators have a high level of control and require their children to act at an intellectual and social level according to their age and abilities. However, they still provide warmth, guidance, and two-way communication. They provide explanations and reasons for the penalties and prohibitions. Children of parents or educators like this will grow up to be independent, assertive to themselves, friendly with peers, and willing to cooperate with parents. Children will also be successful intellectually and socially, enjoy life and have strong and advanced motivation.

2. Authoritarian type

Parents or an educator with an authoritarian type always demands and controls solely because of power, without warmth, guidance, and twoway communication. They control and judge children's behavior to absolute standards. They value obedience, respect for their power and tradition. Children with parental or educator characteristics like this tend to have moderate competence and answer tagging, tend to withdraw socially, and do not have spontanity. Girls will depend on their parents or educators and have no motivation to progress. Boys tend to be more aggressive than other boys.

3. Patient type

Parents or educators who have a patient type will accept, respond, place little demands on their children. Children will be more positive mood and show more vitality than children from authoritarian families. Permissive parents will encourage children to be aggressive and tend to be confident.

4. The abandonment type

Parents with abandonment type pay more attention to their own activities and are not involved with the activities of their children. They don't know where their children are, what they are doing, and who their friends are when they leave the house. They are not interested in events at the children's school, rarely converse with their children, and do not care about their children's opinions. ${ }^{7}$

In this connection, with regard to parenting for children, of course it also has a good impact or purpose, including in this case it is also a form of

${ }^{7}$ Maimunah Hasan, PAUD Pendidikan Anak Usia Dini, (Yogyakarta:Diva Press, 2009), 24-28.

e-ISSN: 2715-4572 p-ISSN: 2716-1439 
togetherness between parents or educators with children in realizing moral values. The existence of this parenting style, with the efforts of an educator or parent to create situations and conditions that can encourage and stimulate children to always be able to behave in accordance with the rules (moral values).

Children who are accustomed and cultured to behave in a moral way, substantially have self-disciplined behavior. Therefore, parents need to arrange it by structuring the physical, social, educational, socio-cultural and psychological environments. And from things like that all too, is nothing but a form of parenting that has been given to children with the assumption that they can create a generation with good morals. ${ }^{8}$

Good parenting, positive environmental attitudes and community acceptance of children's existence will be able to foster a positive self-concept for a child in assessing himself. Children judge themselves based on what is experienced and obtained from the environment. If the community environment can give a good and positive attitude and not give a negative label or label to the child, then the child will feel that he is quite valuable so that a positive self-concept grows. ${ }^{9}$

\subsection{Cognitive learning theory}

${ }^{8}$ Moh. Shochib, Pola Asuh Orang Tua Dalam Membantu Anak Mengembangkan Disiplin Diri, (Jakarta: Rineka Cipta, 2010), 127-128.

${ }^{9}$ Rifa Hidayah, Psikologi Pengasuhan Anak, (Malang: UIN Malang Press, 2009). 16.
Cognitive learning theory developed from Piaget. Vygotsky, and information processing theory. Piaget's theory of cognitive development is one theory that explains how children adapt to and interpret objects and events around them. How do children learn the characteristics and functions of objects. ${ }^{10}$ In cognitive learning theory views learning as a learning process that emphasizes the learning process itself rather than learning outcomes.

Cognitive flow initially appeared as a form of disagreement response to behavioristic learning concepts that considered learning only a matter of stimulus and response (S-R) relationships. According to Asri Budiningsi, learning in the view of followers of the cognitive stream does not only involve the relationship between stimulus and response. However, it is an activity that involves complex thinking processes, meaning that there are activities during the learning process that occur in the individual brain. ${ }^{11}$

The cognitive domain that focuses on intellectual development is the main focus of development. Jean Piaget, emphasized that intellectual development is a very prominent domain in practical activities in the field. 12

${ }^{10}$ Neil J. Salkind, Child Development, (New York: Macmillan Reference USA, 2002), 308.

${ }^{11}$ Asri Budiningsi, Belajar dan Pembelajaran, (Jakarta: Rineka Cipta, 2012), 34.

12Bandi Delphie, Pembelajaran Anak Berkebutuhan Khusus dalam Setting Pendidikan Inklusi, (Jakarta: Hak Cipta, 2009), 40.

e-ISSN: 2715-4572 p-ISSN: 2716-1439 
According to Toeti Soekamto and Udin Saripudin, cognitive theory emphasizes the idea that each piece of information and a situation during the learning process will relate to the whole context of knowledge so that it will be more meaningful. Therefore, the key understanding of cognitive learning theory according to Sugiyono and Hariyanto is (a) the memory system or memory in the brain as long as the individual learning is an active and organized information processor and (b) the initial knowledge of the individual has a very important role in learning process. The development of cognitive learning theory develops in the form of Gestalt theory and constructivist theory.

Cognitive theory is based on the assumption that cognitive abilities are fundamental and that guide the behavior of students. With this cognitive ability, students are seen as individuals who actively build their own knowledge about the world. ${ }^{13}$

\subsection{Affective learning strategies}

Affective learning strategies are strategies that not only aim to achieve cognitive education, but also affective attitudes and skills related to volume that are difficult to measure because they involve a person's awareness that grows from within. The ability of the affective aspect relates to interests and attitudes which can be in the form of responsibility, cooperation, discipline, commitment, confidence, honesty, respect for other people's opinions and the ability to control oneself. All these

\footnotetext{
13Desmita, Psikologi Perkembangan, (Bandung: PT Remaja Rosdakarya, 2005), 45-46.
}

abilities must be part of the learning objectives at school, which will be achieved through appropriate learning activities. In another sense stated that the affective realm greatly influences feelings and emotions.

Affective problems that are psychological in nature and within humans, are difficult to read and measure. However, it can be reviewed / read through a number of indicators. Therefore, affective learning should also use this indicator media to penetrate the conscience and feelings of students, and teachers must be patient and resilient, because to be able to open the veils of students and develop their overall psyche we must use various techniques and methods.

Reading a self-portrait of a person (student) many people worry that what is shown / read is false and different from what is actually the student's inner self. This can happen, in fact it is an affective nature that what today is considered good / right by us on occasion or other conditions becomes incorrect (changes). For this reason, it is necessary to read the various indicators displayed by students, as well as in developing them.

So we cannot force / be ambitious to know everything but throw an effort / stimulus so that students can display their true identity. It is possible for the child to say "I have never stolen," but through the stimulus / media that we throw in learning, students have dialogue and answer them lying because they have actually stolen and then judged that the act was good or bad and new answers and intentions emerged. 
Learning success in the cognitive and psychomotor domains is influenced by the affective conditions of students. Students who have an interest in learning and a positive attitude towards lessons will feel happy learning certain subjects, so that they can achieve optimal learning outcomes. Therefore, to achieve optimal learning outcomes, in designing learning programs and learning activities for students, educators must pay attention to the affective characteristics of students. ${ }^{14}$

\subsection{Affective Aspect Development}

Affective is an aspect related to attitudes and values. Attitude is a psychological term that deals with perception and behavior. The term attitude involves some knowledge of the situation, but the most essential aspect of attitude is the presence of feelings or emotions, a tendency towards actions related to knowledge. ${ }^{15}$

Affective education is very important, to achieve real educational goals. That is, students are able and willing to practice the actions obtained from the world of education in everyday life ${ }^{16}$. The affective aspect is related to a person's willingness to accept and practice the values and norms that are learned. Positively, an example of the affective aspect as a result of learning is an increase in one's appreciation of a value or norm that is believed to be true.

${ }^{14}$ Nunuk Suryani, Strategi Belajar Mengajar, (Yogyakarta: Penerbit Ombak, 2012), 122-

123.

${ }^{15}$ Ibid., 102.

${ }^{16}$ Darmiyati Zuchdi, Humanisasi Pendidikan: Menemukan Kembali Pendidikan Yang Manusiawi, (Jakarta: Bumi Aksara, 2010), 67.
Affective aspects relate to attitudes, emotions, appreciation of values, norms and something that is being studied. 17,18

\section{Methodology}

This study use a qualitative approach with the object of research, namely MAN Insan Cendekia Palu City.

The choice of MAN Insan Cendikia is because the school has a teacher who is also a substitute for parents, in which there is a dormitory that is occupied by every student who goes to MAN Insan Cendikia. In this case a teacher is known as a foster teacher who fosters students both in the classroom and in the dormitory.

The use of qualitative methods in this study with several considerations. First, adapting qualitative methods is easier when faced with multiple realities. Second, it can directly present the nature of the relationship between researchers and informants. Third, this method is more sensitive and adapts better to the many problems being studied so that the discussion is more indepth. ${ }^{19}, 20$

Data were collected using observation techniques, in-depth interviews with principals, teachers, and

${ }^{17}$ Ibid., 98.

18 Rusli, R. (2020). The Role of Family in Preventing Social Conflict in Society From Islamic Perspectives. Hunafa: Jurnal Studia Islamika, 17(1), 108-122.

${ }^{19}$ Ibid., 5.

${ }^{20}$ Nurdin, N., Stockdale, R., \& Scheepers, H. (2013). The Use of Social Media to Gather Qualitative Data: A Case of Government EProcurement Implementation and Use. 24th Australasian Conference on Information Systems (ACIS)

e-ISSN: 2715-4572 p-ISSN: 2716-1439 
students. Researchers also reviewed various written documents. Meanwhile, data analysis was carried out using reduction and verification techniques with various data sources. ${ }^{21}$ The data that has been reduced is then analyzed by confessing the theoretical concepts used in this study.

\section{Result and Discussion}

\subsection{Foster Teacher Patterns at Madrasah Aliyah Insan Cendikia Palu City}

In the era of globalization or the era of free market today, it is an era of quality and quality competition, whoever is qualified is the one who will advance and be able to maintain his existence. Therefore, development and fostering of quality human resources is a necessity that cannot be negotiated to become the main support for an independent national. ${ }^{22}, 23$

Boarding pattern education, especially at MAN Insan Cendika, Palu City, as an alternative for several educational institutions that want an increase in the quality of education for their students, always strive to be the

21 Nurdin, N., \& Yusuf, K. (2020). Knowledge management lifecycle in Islamic bank: the case of syariah banks in Indonesia. International Journal of Knowledge Management Studies, 11(1), 59-80. https://doi.org/10.1504/ijkms.2020.105073

${ }^{22}$ E. Mulyasa, Kurikulum Tingkat Satuan Pendidikan Suatu Panduan Praktis, (Bandung: PT. Remaja Rosdakarya, 2007), 2.

${ }^{23}$ Nurdin, N., Pettalongi, S. S., \& Ahsan, M. N. (2019). Implementation of Teaching Quality Assessment System Using Android. 2019 5th International Conference on Science and Technology (ICST) best educational institution and are in demand by the public. In the process towards quality education, education that is able to exist in global competition requires many factors that participate in accelerating the process of moving towards education. Furthermore, there are many parents who want quality education for their children, especially religious education. But reality has shown not only to parents but to educators / teachers in particular.

MAN Insan Cendikia Palu City, especially those implementing the Boarding School system, has foster teachers who are part of the curriculum in schools who are given duties and responsibilities as guides, directors and coaches for students in improving the quality of knowledge and understanding and positive attitudes of students itself.

Boarding School adalah sebagai suatu tempat pendidikan dan pengajaran yang menekankan pelajaran agama islam dan memperhatikan materimateri dasarn keilmuan yang mendukung dengan mata pelajaran sekolah yang melinatkan peserta didik dan para pendidiknya bisa berinteraksi dalam waktu 24 jam setiap harinya dan didukung asrama sebagai tempat tinggal peserta didik yang bersifat permanen dan juga didukung oleh sistem pengasuhan dari seorang pendidik yang sudah ditunjuk.

As the results of the interview from the Head of Madrasah MAN Insan Cendekia Palu City, namely;

Boarding School is a place of education and teaching that emphasizes Islamic religious lessons and pays attention to basic scientific materials that 
support school subjects that engage students and their teachers.

Educators can interact 24 hours a day and are supported by a dormitory as a permanent residence for students and also supported by a system of care from an appointed educator.

The pattern of foster teachers at MAN Insan Cendikia is one of the activities in terms of fostering and guiding as from the results of the interview above, as well as directing students in terms of improving aspects of knowledge and attitudes of students themselves, besides that foster teachers are considered as substitutes for parents for students in schools and dormitories. This will make students really need the presence of foster teachers. As stated by the principal of MAN Insan Cendikia, Palu City, as follows:

Here the foster teacher is a substitute for the parents as long as the students take education at the MAN Insan Cendikia school, especially in Palu City, which is to provide guidance and direction at any time to the students at the MAN Insan Cendikia Bording School. All of Indonesia has 23 MAN Insan Cendikia in various provinces and the most important thing in delivering the success of students is fostering teacher training. ${ }^{24}$

One of the parenting styles applied in MAN Insan Cendikia Palu City above is a parenting style that is full of understanding and attention in fostering students, so that in this case many students feel spoiled, but based on

\footnotetext{
24Soim Anwar, Kepala Madrasah Insan Cendikia Kota Palu, "Wawancara", Tanggal 27 Juni 2019.
}

informants from one of the foster teachers based on the results of the interview, namely:

I am as a foster teacher who is called a substitute for parents as long as the students are at MAN Insan Cendekia Palu City, conducting coaching and guidance in the form of authoritarian parenting, the reason is that I want students when they make fatal and repeated mistakes, they give up so they will be afraid to make mistakes in the future. Like waking up late and skipping classes during class time as a result late to class or not attending subjects, I give punishment by drying students in the sun with the aim that students will not skip classes again and can wake up on time.

The interview above shows that some foster teachers do authoritarian guidance, with the aim that students can feel the consequences of the mistakes they have made. This is an advantage that students are nurtured and guided in a firm and consistent manner, so that they can instill the desired attitude values, such as being diligent in the morning, following subjects in class according to the hour, respecting teachers and cultivating a disciplined attitude.

Teacher parenting patterns obtained at MAN Insan Cendekia Palu City which is a Boarding School, namely Islamic-based formal education are currently one of the places for parents and the community to educate the religious character of students. The formation of religious character in MAN Insan Cendekia has a larger portion compared to public schools, because 
seeing the behavior and behavior of students is always observed for 24 hours with modern system services and does not seem old-fashioned, with various kinds of guidance and coaching as a form of parenting of each educator who has been given the responsibility to further support and improve the intellectual aspects of students as well as the aspect of attitude which is very important in instilling positive values towards students.

As said by one of the foster teachers at MAN Insan Cendikia, Palu City, as follow:

In my opinion, the existence of a foster teacher pattern that has become part of the curriculum at MAN Insan Cendikia, Palu City, is something that can facilitate the learning process in the classroom, because with coaching and guidance that has been scheduled or not scheduled to become a benchmark how the students themselves receive lessons in class. So it is easy for teachers who teach certain subjects in overcoming the learning difficulties of students themselves because of the assistance from fostering teacher guidance.

The interview above understood that the school in MAN Insan Cendekia is a school with a Boarding School system, which is not only demanded for its role as a classical function in order to maintain Islamic traditional values in students, but also must function more widely in order to respond to global developments. In terms of quality, for example, Boarding School does not only form the personal of religious students but also other personalities such as disciplined, honest, diligent and others.
Which is a reflection of the values of Islam itself. In simple terms, it can be said that the Boarding School system should become a system for tafaqqoh fi al diin in a broad sense.

\subsection{Foster Teacher Efforts in Improving Cognitive and Affective Domains}

The implementation efforts of foster teachers in fostering students are very important activities, especially schools that implement the Boarding School system, at any time foster teachers can control their students, especially in the aspects of knowledge and attitudes. The learning problems experienced by students during the learning process can be discussed and scheduled to find solutions so that students are able to overcome during the next learning process, the efforts made by foster teachers as expressed by one of the foster teachers in MAN Cendikia personnel of Palu City, as follows: ${ }^{25}$

The efforts we make in solving learning problems for students in the learning process is to provide the widest possible opportunity for students to ask what is the difficulty in learning, so that we as foster teachers can tips so that students can undergo the learning process with a good understanding and can increase knowledge and understandment of previous learners.

The efforts made by one of the foster teachers above are none other than providing solutions that can make students easy in doing school work and

\footnotetext{
${ }^{25}$ Catur Wulandari, Guru Fisika MAN Insan Cendikia Kota Palu, "Wawancara", Tanggal 10 Juli 2019. 
provide good understanding, so that students are motivated to study hard and construct their knowledge and skills.

The things that also need to be considered by foster teachers are how the students have good learning outcomes in school and achieve the desired targets. So that it can improve the knowledge aspects of students. As stated by one of the foster teachers who teach Mathematics, as follows:

As foster teachers we hold meetings at least twice a week for briving and ask all the complaints faced by students in the learning process in class. What subjects are the complaints and what kind of learning outcomes they get are bad or not. ${ }^{26}$

The efforts carried out by one of the foster teachers above are none other than for the sake of supporting the success of students in their cognitive aspects to achieve the students' academic completeness themselves. In this case, the understanding and knowledge of students will increase. Analysis which is the most important aspect for students is also usually carried out by foster teachers in the form of materials in Mathematics and Physics subjects.

Various kinds of activities and coaching according to researchers that the presence of structured foster teachers and an obligation, especially in MAN Insan Cendikia, Palu City, is something that must be used as guidelines and learning in order to

26Fathul, Guru Matematika MAN Insan Cendikia Kota Palu, "Wawancara”, Tanggal 1 Juli 2019. produce students who are useful in society who are able to solve problems faced in the challenges of the modern world and behavior. which is the spearhead of a religious human being. ${ }^{27}$

One of the subjects which is robotics. The benefits of learning robotics are stimulating systematic and structured thinking in solving a problem, improving fine motor skills in students, increasing imagination skills in designing robots because in designing robots it requires creativity, trains teamwork and increases self-confidence and accepts and respects other people's opinions and dare to express or display creative ideas and practice patience and persistence in making a project.

The description above can be concluded that in foster teacher activities it is very beneficial for students in MAN Insan Cendikia, because creating a robot is not as easy as it seems. In making a robot, the formula for speed, acceleration, force and burden is needed.

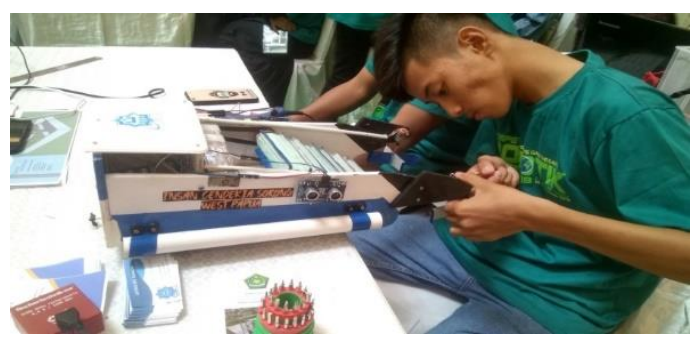

Guidance in robotic activities carried out by one of the foster teachers

27 Evita, E., Syahid, A., \& Nurdin, N. (2019). Understanding Students' Learning Outcomes Differences Through the Application of the Market Place Activity Type of Cooperative Learning Model and the Application of Conventional Learning Models International Journal of Contemporary Islamic Education, 1(1), 6785. 
has produced good achievements and has become an advantage in MAN Insan Cendikia, Palu City, with the recently won achievements proof that the knowledge and understanding and analysis and skills of students has increased.

Bloom's theory used by researchers in the classification of cognitive and affective domains, namely researchers use in field interviews to get good results. In the results it was found that students were continuously nurtured and given a good stimulus through learning guidance to other activities that could train the abilities and understanding of students. So that there is a good response as in the results of the research that students, especially those in MAN Insan Cendikia, Palu City, get various kinds of achievements through competitions and other training activities. In this case the researcher has got the results that there is an increase in cognitive and affective aspects through various kinds of activities, coaching and guidance to students in MAN Insan Cendikia, Palu City.

\section{Conclusion}

Based on the results of the research and discussion previously described, it can be concluded that the pattern of foster teachers applied in MAN Insan Cendekia Palu City is a form of activity and guidance that is relative and consistent, and a series of active efforts that make a large contribution to students, in improve intellectual / academic aspects as well as a good attitude.
So that the foster teacher pattern is used as a series of activities as a vehicle to educate, nurture and socialize children in developing their abilities, in order to achieve family, community and school expectations. Some educators who serve as foster teachers apply authoritarian parenting with the aim that students are clear and do not repeat mistakes, and also authoritative parenting which provides more understanding and good guidance without heavy pressure and punishment.

\section{REFERENCES}

Abdul Aziz, Hamka, Karakter Guru Profesional, Melahirkan Murid Unggul Menjawab Tantangan Masa Depan, Jakarta: PT Al-Mawardi Prima, Cet: IV, 2016.

Abdul Kader, Dkk, Dasar-Dasar Pendidikan, Jakarta: Kencana Media Group, 2012.

Arikunto,Suharsimi, Prosedur Penelitian Ilmiah, Suatu Pendekatan Praktek,Ed. II, Cet. IX ; Jakarta : Rineka Cipta, 1993.

Arifin, Penelitian Kualitatif dan Ilmu-ilmu sosial dan Keagamaan, 2011.

Ari, Donal, Instroduction To Research, Terj. Arif Rahman, PengantarPenelitian dan Pendidikan, Surabaya: Usaha Nasinal, TT.

Asrul, dkk, Evaluasi Pembelajaran, Medan: Perdana Mulya Sarana, 2014.

B. Milles, Matthew, et.al, Qualitative Data Analisys, diterjemahkan oleh Tjetjep Rohendi Rohidi dengan judul Analisis DataKualitatif, buku Sumber tentang Metode-metode Baru, Cet.I; Jakarta: UI-Press, 1992. 
Baharuddin, H, Pendidikan \& Psikologi Perkembangan, Jogjakarta: Ar-Ruzz Media, 2014.

Cholid Narbuku dan Abu Ahmadi, Metodologi Penelitian, Jakarta: Bumi Aksara, 2000.

De Landsheere, Viviane, Evaluation in Education International Progress, an International Ruilew-Sereis. Permagon Press Oxford New YorkFrankfurt, 1997.

Delphie, Bandi, Pembelajaran Anak Berkebutuhan Khusus dalam Setting Pendidikan Inklusi, Jakarta: Hak Cipta, 2009.

Desmita, Psikologi Perkembangan, Bandung: PT Remaja Rosdakarya, 2005.

Evita, E., Syahid, A., \& Nurdin, N. (2019). Understanding Students' Learning Outcomes Differences Through the Application of the Market Place Activity Type of Cooperative Learning Model and the Application of Conventional Learning Models International Journal of Contemporary Islamic Education, 1(1), 67-85.

Haidar dan Pasa, Nurgaya, Pendidikan Islam dalam Mencerdaskan Bangsa, Jakarta: Rineka Cipta, 2012.

Hartono dan Azis, Arnicun, Ilmu Sosial Dasar, Jakarta: Bumi Aksara, tt.

Hasan, Chalidjah, Dimensi-Dimensi Psikologi Pendidikan, Surabaya: AlIkhlas, 1994.

Herdiansyah, Haris, Metodologi Penelitian Kuantitatif, Kualitatif dan $R \& D$, Bandung: Alfabeta, 2011.

H. Schunk, Dale, Motivasi dalam Pendidikan, Teori, Penelitian dan Aplikasi, Jakarta: Permata Puri Media, 2012.

Ibnu Katsir, Tafsir Ibnu Katsir, Surabaya: Bina Ilmu, 2004.
Ida, Rachmad, Metode Analisis isi, Penelitian Kualitatif, Ed. Revisi, Jakarta: PT Raja Grafindo Persada, 2001.

Imam Barnadib, Sutari, Pengantar Ilmu Pendidikan Sistematis, Yogyakarta: Ombak(IKAPI), 2013.

J. Salkind, Neil, Child Development, New York: Macmillan Reference USA, 2002.

K. McEwan, Elaine, 10 Karakter yang Harus Dimiliki Guru yang Sangat Efektif, Jakarta: PT. Indeks, 2016.

Latipah, Eva, Pengantar Psikologi Pendidikan, Yogyakarta: PT. Pustaka Insan Madani, 2012.

Masganti, Perkembangan Peserta Didik, Medan: Perdana Publishing, 2012.

Margono, Penelitian Pendidikan (Cet. II; Jakarta: Putra Rineka Cipta, 2000.

Moleong, Lexy J, Metodologi Penelitian Kualitatif, Bandung : Remaja Rosdakarya, 2002.

Mulyasana, Dedi, Pendidikan Bermutu dan Berdaya Saing, Bandung: PT Remaja Rosdakarya, 2012.

Mushaf Al-quran Terjemahan, Departemen Agama RI, Bogor: Kaamil Al- Qur'an, tt.

Mushlich, Masnur, Penilaian Berbasis Kelas dan Kompetensi, Bandung: PT Refika Aditama, 2010.

Narbuku, Cholid dan Ahmadi, Abu, Metodologi Penelitian, Jakarta: Bumi Aksara, 2000.

Nasution, S, Metode Research Penelitian Ilmiah, Cet. VII ; Jakarta : Bumi Aksara, 2004.

Nasution, S, Berbagai Pendekatan dalam Proses Belajar \& Mengajar, Jakarta: PT. Bumi Aksara, 2015.

Nurdin, N., Stockdale, R., \& Scheepers, H. (2013). The Use of Social Media to Gather Qualitative Data: A Case of Government EProcurement Implementation and

e-ISSN: 2715-4572 p-ISSN: 2716-1439 
Use. 24th Australasian Conference on Information Systems (ACIS)

Nurdin, N., \& Yusuf, K. (2020). Knowledge management lifecycle in Islamic bank: the case of syariah banks in Indonesia. International Journal of Knowledge Management Studies, 11(1), 59-80. https://doi.org/10.1504/ijkms.20 20.105073

Nurdin, N., Pettalongi, S. S., \& Ahsan, M. N. (2019). Implementation of Teaching Quality Assessment System Using Android. 2019 5th International Conference on Science and Technology (ICST)

Prayetno dan Anti, Erman, Dasar-Dasar Bimbingan dan Konseling, Jakarta: Rineka Cipta, 2004.

Rusli, R. (2014c). Teaching Usul al-Fiqh: A Multicultural Education Model. Al-Tahrir: Jurnal Pemikiran Islam, 14(2), 447-464.

Rusli, R. (2020). The Role of Family in Preventing Social Conflict in Society From Islamic Perspectives. Hunafa: Jurnal Studia Islamika, 17(1), 108-122.

Salim dan Syahrum, Metodologi Penelitian Kualitatif, Bandung: Cita Pustaka Media, 2007.

Setiawan, Irfan, Pembinaan dan Pengembangan Peserta Didik Pada Institusi Pendidikan Berasrama, Yogyakarta: CV. Writing Revolution, 2013.

Sudarto, Metodologi Penelitian Filsafat, Jakarta: Raja Grafondo Persada, 2002.

Sugiyono, Metode Penelitian Pendidikan, Bandung: Alfabeta, 2011.

Sukmadinata, Nana Syaodih, Metode Penelitian Pendidikan, (Bandung: PT Remaja Rosdakarya, 2010.
Sunaryo Kuswana, Wowo, Taksonomi Kognitif; Perkembangan Ranah Berpikir, Bandung: Remaja Rosdakarya, 2012.

Supiana, Sistem Pendidikan Madrasah Unggulan di MAN IC, Badan Litbang Dan Diklat Depag RI, 2008.

Surakhmad, Winarno, Dasar dan Teknik Research Pengantar Metodologi Ilmiah, Ed.VI, Bandung, 1978.

Suryani, Nunuk, Strategi Belajar Mengajar, Yogyakarta: Penerbit Ombak, 2012.

Suprihatiningrum, Jamil, Strategi Pembelajaran Teori \& Aplikasi, Jogjakarta: Ar-Ruzz Media, 2016.

Suwarno, Wiji, Dasar-Dasar Ilmu Pendidikan, Jogjakarta: Ar-Ruzz Media, 2013.

Thoha, Miftah, Pembinaan Organisasi (Proses Diagnosa \& Intervensi), Jakarta: PT Raja Grapindo Persada, 2003.

W.S, Sarlito, Psikologi Remaja, Jakarta: Raja Grapindo Persada, 2002.

Yanis, Muhajirin, "Sistem Pengelolaan Madrasah Berasrama dalam Meningkatkan Mutu Pendidikan (Studi Kasus pada MAN Insani Cendikia Gorontalo sebagai Madrasah Program Khusus Berstandar Internasional)" Disertasi Pascasarjana, UIN Alauddin, Makassar, 2010.

Yaumi, Muhammad dan Damapoli, Muljono, Action Research, Jakarta: Prenada Media Group, 2014.

Zuchdi, Darmiyati, Humanisasi Pendidikan: Menemukan Kembali Pendidikan Yang Manusiawi, Jakarta: Bumi Aksara, 2010. 